\title{
INTEGRATED SCIENCE TEACHERS' SELF-EFFICACY BELIEFS AND IT'S IMPACT ON THEIR INSTRUCTIONAL PRACTICE
}

\author{
Collins Owusu-Fordjouri, \\ James Awuni Azure', \\ Charles Kwesi Koomson ${ }^{1}$ \\ ${ }^{1}$ Department of Integrated Science Education, \\ University of Education, Winneba, \\ P.O. Box 25, Winneba, \\ Ghana \\ ${ }^{2}$ Department of Biology Education, \\ University of Education, Winneba, \\ P.O. Box 25, Winneba, \\ Ghana
}

\begin{abstract}
:
This study investigated the self-efficacy beliefs of Integrated Science Teachers in Senior High Schools and its impact on their instructional practice. The study employed the mixed method approach adopting the descriptive survey design. The study employed the use of questionnaire, interview and observation to collect data from 138 participants. Findings of the study observed that majority of the teachers had the requisite qualification to teach at the senior high school level, not all of them can confidently teach Integrated Science as an integrated whole. Some participants were of the view that since the subject encompass the various branches of science with the three main branches of the natural science dominating, it is imperative that more integrated science specialist are employed to handle the subject as an integrated whole and not in aspects as majority of the schools in the country are doing. Again, it was realised from this study that, teachers confidence level were low whenever they are teaching aspects that are not in their field of study. The study therefore recommends that regular, effective and efficient organisation of science workshops and seminars, continuous discussions about issues relating to the effective teaching of science in Senior High Schools should be held at least once every two years to enable teachers be updated with current practices in education. Again stakeholders of education should institute a scholarship package to enable more teachers to be trained to teach Integrated Science as an integrated whole to boost confidence in students.
\end{abstract}

i Correspondence: email owusufcollins@gmail.com 
Keywords: self-efficacy beliefs, instructional practice, integrated science, teaching, learning

\section{Introduction}

Beliefs and ideas that teachers carry influence their classroom work. Bernat and Gvozdenko (2005), states that students begin teacher education programmes with their own ideas and beliefs about what it takes to be a successful teacher. These preconceptions are formed from observation of teachers, good and bad, over several years (Donaghue, 2003). For any education system to flourish and achieve its goals, the role of teachers has to be paramount. The quality of training that teachers receive and the systematic support for their professional growth are what would ensure that education reaps the full potentials of teachers' contribution to quality education. The training given to such teachers should be such that it makes them have confidence in themselves as they carry on with the teaching and learning process that builds their self-efficacy beliefs.

The dearth of integrated science teachers in Ghana and the lack of teaching skills and competencies among teachers are the result of their poor instructional approaches (Anamuah-Mensah \& Benneh, 2010; Jones, 2008). This has also resulted in the rote teaching of the subject since teachers and students alike concentrate much on examinations than knowledge acquisition for lifetime experience.

Self-efficacy is the personal belief that one is capable of performing in an appropriate and effective manner to attain certain goals (Ormrod, 2006). It exists in many domains of human functioning, including both professional and private behaviour. Specifically, in an educational context, teacher self-efficacy is the teacher's own belief in his/her ability to plan instruction and accomplish instructional objectives in a manner that instill learning and acquisition of the required knowledge.

Teacher self-efficacy is a broader concept which needs proper and in-depth scrutiny and attention, and in fact, high self-efficacy underlies and enables successful use of professional knowledge and skills, conversely, low self-efficacy inhibits effective use of professional knowledge and skills at work place. Thus, teacher self-efficacy is the persons' own personal trait which enables them to use their potentials to enhance positive instructional activities. It should be acknowledged that teacher self-efficacy is related to "perseverance;" the stronger the self-efficacy, the greater the perseverance and the greater the perseverance, the greater the likelihood that the teaching behaviours will be successful. Teacher self-efficacy is a construct that was developed within the context of Bandura's social cognitive theory. Bandura defined self-efficacy as the belief about one's own capabilities to organise and execute a certain task (Bandura, 1997). Self-efficacy beliefs influence thought patterns and emotions, which in turn enable or inhibit actions.

According to Bandura's theory, self-efficacy has two components: efficacy expectation and outcome expectancy. The former is the conviction that one has the ability, knowledge, and skills to successfully execute the behaviour or actions required to produce the desired outcome(s). The latter represents a person's estimate of the likely 
consequences (impact) of performing a task at the self-expected level of performance. This study therefore investigates the self-efficacy beliefs on Integrated Science teachers and its impact on their instructional practice.

\section{Objective of the study}

The objective of the study was to determine the self-efficacy beliefs of Integrated Science teachers and its effect on their instructional practice.

\section{Methodology}

The study employed the descriptive survey design using the mixed method approach. This design helps to utilize the elements of both qualitative and quantitative research methodologies often within the same study. The survey research design enables researchers to get first-hand undistorted information from the research subjects which influence the study. The concurrent triangulation design under the mixed-method approach was adopted as a means of data analysis and presentation. This study employed simple random sampling to select 138 Integrated Science teachers in the Central Region of Ghana. These teachers were the participants for the study. The study employed the use of questionnaire and observation checklist as quantitative instruments and interview as a qualitative instrument. Closed-ended structured questionnaire was used. The five likert-type scale ranged from "Strongly agree" (SA), "Agree" (A), "Uncertain" (U), "Disagree" (D) to "Strongly Disagree" (SD). Cronbach Alpha reliability coefficient of 0.74 was used to determine the reliability of the questionnaire.

Data for the study were collected in sequence. Thus the quantitative data was first collected followed by the qualitative data.

The quantitative data were analysed into simple frequencies and percentages whereas thematic analysis were used for the qualitative data. Statistical Package for Social Sciences (SPSS) version 20 was used for the quantitative data analysis. The qualitative data were however, transcribed and organised into themes.

\section{Results and Discussion}

One hundred and thirty-eight respondents were sampled for the study. This comprised of 105 males and 33 females. The males constitute the larger population about $76 \%$ because science is seen as a masculine programme hence females tend to move to the arts where there is enough reading and less calculation. Females are generally said to be acalculia while males are said to be agraphia.

Among the 138 respondents, 80 have had the BSc/BEd qualification while 58 had masters certificates ranging from MSc, MEd and MPhil. This shows that the teachers have had the requisite qualification to teach in a second cycle institutions in the country. Their 
having the required qualification also meant that they have the needed knowledge and skills about the subject matter.

The study sought to find out the self-efficacy beliefs of teachers. A questionnaire was first administered to find out the efficacy-beliefs of these Integrated Science teachers and their responses have been presented in the Table 1 below;

Table 1: Teachers self-efficacy beliefs towards integrated science teaching

\begin{tabular}{|c|c|c|c|c|c|}
\hline Premise & $\begin{array}{l}\text { SA } \\
\text { F } \%\end{array}$ & $\begin{array}{c}\text { A } \\
\text { F } \%\end{array}$ & $\begin{array}{l}\text { UN } \\
\text { F \% }\end{array}$ & $\begin{array}{c}\mathrm{D} \\
\mathrm{F} \%\end{array}$ & $\begin{array}{l}\text { SD } \\
\text { F \% }\end{array}$ \\
\hline $\begin{array}{l}\text { I believe confidently that I can teach Integrated } \\
\text { science as an Integrated whole. }\end{array}$ & $\begin{array}{c}40 \\
(29.0)\end{array}$ & $\begin{array}{c}78 \\
(56.5)\end{array}$ & $\begin{array}{c}14 \\
(10.1)\end{array}$ & $\begin{array}{c}5 \\
(3.6)\end{array}$ & $\begin{array}{c}1 \\
(0.7)\end{array}$ \\
\hline $\begin{array}{l}\text { I believe the Integrated science subject can be taught } \\
\text { by one teacher. }\end{array}$ & $\begin{array}{c}23 \\
(16.7)\end{array}$ & $\begin{array}{c}59 \\
(42.8)\end{array}$ & $\begin{array}{c}15 \\
(10.9)\end{array}$ & $\begin{array}{c}29 \\
(21.0)\end{array}$ & $\begin{array}{c}12 \\
(8.7)\end{array}$ \\
\hline $\begin{array}{l}\text { There are some aspects of the subject that I will need } \\
\text { a helping hand when teaching it. }\end{array}$ & $\begin{array}{c}36 \\
(26.1) \\
\end{array}$ & $\begin{array}{c}69 \\
(50.0)\end{array}$ & $\begin{array}{c}22 \\
(15.9)\end{array}$ & $\begin{array}{c}11 \\
(8.0)\end{array}$ & $\begin{array}{c}0 \\
(0.0)\end{array}$ \\
\hline $\begin{array}{l}\text { I believe personal development training will enhance } \\
\text { my content knowledge as well as my classroom } \\
\text { management skills. }\end{array}$ & $\begin{array}{c}60 \\
(43.5)\end{array}$ & $\begin{array}{c}66 \\
(47.8)\end{array}$ & $\begin{array}{c}11 \\
(8.0)\end{array}$ & $\begin{array}{c}1 \\
(0.7)\end{array}$ & $\begin{array}{c}0 \\
(0.0)\end{array}$ \\
\hline $\begin{array}{l}\text { Certain aspects of Integrated Science should be } \\
\text { taught by specialized resource person. }\end{array}$ & $\begin{array}{c}36 \\
(26.1) \\
\end{array}$ & $\begin{array}{c}80 \\
(58.0) \\
\end{array}$ & $\begin{array}{c}8 \\
(5.8) \\
\end{array}$ & $\begin{array}{c}10 \\
(7.2)\end{array}$ & $\begin{array}{c}4 \\
(2.9) \\
\end{array}$ \\
\hline $\begin{array}{l}\text { Integrated Science should be taught with much } \\
\text { activities. }\end{array}$ & $\begin{array}{c}70 \\
(50.7)\end{array}$ & $\begin{array}{c}55 \\
(39.9)\end{array}$ & $\begin{array}{c}10 \\
(7.2)\end{array}$ & $\begin{array}{c}3 \\
(2.2)\end{array}$ & $\begin{array}{c}0 \\
(0.0)\end{array}$ \\
\hline
\end{tabular}

This was to obtain from teachers, how much they believe in themselves and their ability to teach Integrated Science in the second cycle institutions. Their responses indicated that $85.5 \%$ (118) of the teachers believed that they can confidently teach Integrated Science as an integrated whole; $10.1 \%$ (14) of them were however uncertain of their ability to confidently teach Integrated Science. A small percentage of $4.3 \%$ said they could not confidently teach integrated science. Approximately 60\% (82) of them agreed that the Integrated Science subject can be taught by one teacher; while $29.7 \%$ of them disagreed to that statement. Approximately $10.9 \%$ (15) of the teachers were in disagreement to the fact that Integrated Science can be taught by a single teacher. Eighty-five percent (118) of the respondents agreed that the volume of the Senior High School Integrated Science syllabus is voluminous while $3.6 \%$ (5) of the respondents disagreed; $10 \%$ (15) of the respondents were undecided on the issue. in addition to that, $76 \%$ (104) respondents agreed that they will need a helping hand to teach some of the concepts in Integrated Science, $8.0 \%$ (11) respondents however, disagreed while15.9\% (22) respondents were not certain on that. On the issue of personal development, 91.3\% (126) respondents agreed that personal development training will enhance their teaching skills and update them on the new trends in the curriculum while $0.7 \%$ (1) respondent disagreed; $7.9 \%$ (11) respondents were however undecided. Majority of the respondents 90.6\% (125) agreed that Integrated Science should be taught with much activities whiles $2.2 \%$ (3) disagreed to that. $7.2 \%$ (10) respondents however were undecided.

Data on self-efficacy beliefs of Integrated Science teachers obtained through interview suggests that majority of the respondent have positive self-efficacy beliefs 
towards their instructional practice. Concerning the teachers' ability to teach Integrated Science as an integrated whole, majority of them asserted that they can teach it as a whole with only few teachers expressing difficulties in teaching the subject as an integrated whole.

On the issue of the subject being taught by a single teacher, , majority of the respondents agreed that one person teaching Integrated Science is very tedious and will hinder the completion of the syllabus. On the volume of the Integrated Science syllabus, the majority of the teachers reiterated that the syllabus is voluminous and should be looked at although efforts are being made every year to complete it.

The teachers also informed the Researcher about the need to get a helping hand from another person during the instructional period.

From the data obtained using the questionnaire, it implies that majority of the teachers have positive self-efficacy beliefs towards their instructional practice. However, there are some few individuals who doubted their ability to teach the subject because of their area of specialisation. Integrated Science comprises many aspects of both natural and applied science hence for a teacher to be able to teach the subject, they must have adequate knowledge on the various aspects of science. Having adequate knowledge on the various aspects of science will enable them to be confident in their lesson delivery. Again, having adequate knowledge will boost your self-efficacy beliefs as you are always in the known of what you are doing which will also affect your instructional methodologies. The findings are in consonance with Wimsatt (2012), who concur that a person's self-efficacy is a person's own belief in his/her personal capabilities to perform a specific task. It is what motivates a person to accomplish a goal. Many studies outlined the importance of the teacher's self-efficacy, and how it is reflected in the teacher's classroom. It is how a teacher believes in his/her own effectiveness and ability to practically overcome any challenge related to student learning. Elloitt (2010) shows that when teachers believe they can succeed in teaching any subject or lesson, they are more likely to do so. A teacher's high self-efficacy is obviously an essential factor in effective teaching and students' achievement, as it brings positive and enthusiastic attitudes in the classroom. It is important to acknowledge that the subject matter of the curriculum that the teachers are required to teach influence the teachers' own perception of their selfefficacy, as some teachers may have higher efficacy levels in one subject compared to other subjects (Mansfield \& WoodsMcConney, 2012).

Some qualitative data gathered from the respondents has it that;

"I am a trained teacher so I believe confidently that I can teach all aspects of Integrated Science." (Teacher 4)

"No. this is because aspect teaching enhances my specialty in an area to help me to teach it better." (Teacher 2) 
"I can teach Biology, Chemistry, Physics and Agricultural Science. It's not a problem at all." (Teacher 1)

"Yes I can teach all the aspects. Personally, I believe it involves so much of a science and one needs to be able to master all aspects before you can confidently teach the subject as a whole." (Teacher 3)

"I cannot handle the subject as an integrated whole because I majored in chemistry and know little of biology and agriculture science if you tell me to handle it as a whole, I may not be able to teach especially the biology aspects of the subject." (Teacher 6)

"As for me, I will be able to teach it as a whole because the syllabus will serve as a guide to me and also I will be reading from other sources that will supply me with much information about the topic I will be teaching in any particular day." (Teacher 5)

The qualitative data gathered indicate that, these teachers can teach the subject with ease and are very confident in themselves. This self confidence has an impact on the teachers efficacy-beliefs which affects their teaching.

An observation was done to ascertain the teachers level of confidence on their instructional practice. Here, the researcher used an observation checklist to collect the data on the their instructional practice. The table below presents the data obtained.

Table 2: Influence of teachers self-efficacy beliefs on lesson planning and preparation

\begin{tabular}{|l|c|c|c|c|c|}
\hline Premises & VG & $\mathbf{G}$ & $\mathbf{S}$ & $\mathbf{P}$ & $\mathbf{A}$ \\
& $\mathbf{F} \%$ & $\mathbf{F} \%$ & $\mathbf{F} \%$ & $\mathbf{F} \%$ & $\mathbf{F} \%$ \\
\hline Exhibit knowledge on subject. & 18 & 16 & 0 & 0 & 0 \\
& $(52.9)$ & $(47.1))$ & $(0)$ & $(0)$ & $(0)$ \\
\hline Achievable and measurable lesson objectives. & 11 & 21 & 2 & 0 & 0 \\
& $(32.4)$ & $(61.8)$ & $(5.9)$ & $(0)$ & $(0)$ \\
\hline Plan for differences in learners' need and ability. & 12 & 18 & 4 & 0 & 0 \\
& $(35.3)$ & $(52.9)$ & $(11.8)$ & $(0)$ & $(0)$ \\
\hline Planning connects with and challenges students & 3 & 28 & 0 & 3 & 0 \\
present knowledge and skills. & $(8.8)$ & $(82.4)$ & $(0)$ & $(8.8)$ & $(0)$ \\
\hline
\end{tabular}

Key: VG = Very Good; G = Good; S = Satisfactory; $\mathrm{P}=$ Poor; $\mathrm{A}=$ Absent

From Table 2, it was evident among the 34 teachers observed in the study, $100 \%$ (34) exhibited knowledge on subject matter; about $53 \%$ (18) had very good knowledge of the subject matter while $47 \%$ (16) exhibits good knowledge of the subject matter. Approximately 94\% (32) of the teachers observed had measurable and achievable lesson objectives whiles $6 \%$ (2) of the respondents had a lesson plan that can be achieved but not within time. Again, about $88 \%$ (30) of the teachers plan for differences in learners need and ability during lesson while $12 \%$ (4) did not actually focused on that. All the teachers $(100 \%)$ however plan lessons that connect with the students' present knowledge and skills. 
It was evident that Integrated Science teachers in the Central Region of Ghana had adequate knowledge of the subject matter. This knowledge affected their preparation positively because they were able to include relevant materials and activities that will elicit learning in students. The subject matter knowledge level of a teacher on the topic has a direct bearing on the students' understanding of subject matter (Conant, 1963).

The results indicated that Integrated Science teachers' efficacy beliefs affected their instructional skills. This data suggest that majority of the teachers had relevant lesson objectives prior to the instructional period (50\%); also, an introduction to the lesson was relevant to the lesson (85.3\%).

Again, $91.4 \%$ of the teachers were able to engage students in the instructional period which is evidence of their beliefs in themselves and their ability to teach the subject. Research by Coladarci (1992), suggests that teachers who have high self-efficacy have been found to exhibit higher levels of professional commitment, another factor suggesting they may be more motivated to attend, participate, learn new things and to inculcate them in their instructional process. They are also able to deliver their lessons in a sequential and systematic manner devoid of many difficulties. This was the case of the respondents as $97 \%$ of them had very positive instructional delivery methods.

\subsection{Influence of teachers' self-efficacy beliefs on instructional skills}

Data on the influence of teachers' self-efficacy beliefs on their instructional practice is presented in the Table 10.

Table 10: Influence of teachers' self-efficacy on instructional skills

\begin{tabular}{|l|c|c|c|c|c|}
\hline Premises & $\begin{array}{c}\text { VG } \\
\text { F \% }\end{array}$ & $\begin{array}{c}\text { G } \\
\text { F \% }\end{array}$ & $\begin{array}{c}\text { S } \\
\text { F \% }\end{array}$ & $\begin{array}{c}\text { P } \\
\text { F \% }\end{array}$ & $\begin{array}{c}\text { A } \\
\text { F \% }\end{array}$ \\
\hline State lesson objectives & 7 & 10 & 6 & 7 & 4 \\
& $(20.6)$ & $(29.4)$ & $(17.6)$ & $(20.6)$ & $(11.8)$ \\
\hline Effective and relevant introduction & 12 & 17 & 5 & 0 & 0 \\
& $(35.3)$ & $(50.0)$ & $(14.7)$ & $(0)$ & $(0)$ \\
\hline Engages students in the instructional process & 14 & 17 & 3 & 0 & 0 \\
& $(41.2)$ & $(50.0)$ & $(8.8)$ & $(0)$ & $(0)$ \\
\hline Systematic and sequential presentation of lesson & 18 & 15 & 1 & 0 & 0 \\
& $(52.9)$ & $(44.1)$ & $(2.9)$ & $(0)$ & $(0)$ \\
\hline Identifies and use opportunities for accidental & 14 & 9 & 7 & 2 & 2 \\
teaching & $(41.2)$ & $(26.5)$ & $(20.6)$ & $(5.9)$ & $(5.9)$ \\
\hline Focuses students attention by using motivational & 5 & 18 & 9 & 0 & 2 \\
techniques & $(14.7)$ & $(52.9)$ & $(26.5)$ & $(0)$ & $(5.9)$ \\
\hline
\end{tabular}

Key: VG = Very Good; G = Good; $\mathrm{S}=$ Satisfactory; $\mathrm{P}=$ Poor; $\mathrm{A}=$ Absent

The data from Table 10 suggest that $50 \%$ (17) of the teachers observed had relevant lesson objectives prior to the instructional period; $21 \%$ (7) teachers had their objectives poorly stated while $12 \%$ (4) had no objectives for the lesson. In addition, 85\% (29) had very relevant introduction to the lesson. 
Again, majority of the teachers $(91.2 \%, 32)$ were able to engage students in the instructional period while $8.8 \%$ (3) teachers engage a handful of students during instruction. On the issue of lesson presentation, it was evident that $97 \%$ (33) of the teachers presented their lesson in a systematic and sequential manner while 3\% (1) of them had few challenges in the lesson delivery.

\subsection{Influence of teachers' self-efficacy beliefs on their communication skills}

Data collected from respondents on the influence of teachers' self-efficacy beliefs on their communication skills is presented in Table 11 below.

Table 11: Influence of teachers efficacy beliefs on their communication skills

\begin{tabular}{|l|c|c|c|c|c|}
\hline Premises & VG & $\mathbf{G}$ & $\mathbf{S}$ & $\mathbf{P}$ & $\mathbf{A}$ \\
$\mathbf{F} \%$ & $\mathbf{F} \%$ & $\mathbf{F} \%$ & $\mathbf{F} \%$ & $\mathbf{F} \%$ \\
\hline Communicate with confidence and enthusiasm. & 20 & 14 & 0 & 0 & 0 \\
& $(58.8)$ & $(41.2)$ & $(0)$ & $(0)$ & $(0)$ \\
\hline Communicates to the understanding of the students. & 24 & 10 & 0 & 0 & 0 \\
& $(70.6)$ & $(29.4)$ & $(0)$ & $(0)$ & $(0)$ \\
\hline Use audible voice during teaching. & 24 & 10 & 0 & 0 & 0 \\
& $(70.6)$ & $(29.4)$ & $(0)$ & $(0)$ & $(0)$ \\
\hline Use appropriate and accurate oral and & 21 & 13 & 0 & 0 & 0 \\
written communication. & $(61.8)$ & $(38.2)$ & $(0)$ & $(0)$ & $(0)$ \\
\hline Avoid overuse of phrases. & 10 & 17 & 3 & 4 & 0 \\
& $(29.4)$ & $(50.0)$ & $(8.8)$ & $(11.8)$ & $(0)$ \\
\hline
\end{tabular}

Key: VG = Very Good; G = Good; $\mathrm{S}=$ Satisfactory; P = Poor; A = Absent

Majority of the teachers $(98.7 \%)$ were found to communicate with confidence and to the understanding of the students. They also use audible voice during teaching which makes it easy for students to hear what they say in class (100\%). The oral and written language used were very appropriate and not beyond the comprehension of the students (100\%). Although some teachers overuse phrases in their instructional process, majority of the teachers $(79.4 \%)$ tried as much as possible to avoid the overuse of phrases in the same sentences while $12 \%$ (4) were consistently overused phrases in their lesson delivery.

Pajares (1992) found that there was a strong relationship between teachers' educational beliefs and their planning, instructional decisions, and classroom practices and that educational belief of teachers plays a pivotal role in their acquisition and interpretation of knowledge and subsequent teaching behaviour. Indeed, it seems that "beliefs are far more influential than knowledge in determining how individuals organize and define tasks and problems and are stronger predictors of behaviour. These beliefs have a greater tendency to influencing one's instructional practice and consequently affects your classroom environment.

This is in agreement with Kenneth (2007), who observed that without communication, the teaching and learning process will not take place. Therefore, teachers with good communication skills will create a more successful teaching and learning ambience for the students. On the other hand, someone with great communication skills 
has the potential to influence others and effective communication strategies will lead to success (Guerrero \& Floyd, 2006). The study found out those Integrated Science teachers has very good communication skills which affected their instructional process. A study by Jurik (2014) clearly highlights the importance of communication between teachers and students, they stated that verbal teacher-student interactions and student characteristics are meaningful for student learning and motivation.

\section{Conclusion}

Self-efficacy beliefs are judgments of how well one can perform courses of action required to deal with forthcoming circumstances. An individual develops specific beliefs about his /her own ability to cope, or self-efficacy. Teacher self-efficacy is the teacher's beliefs in his/her capability or competency to successfully organize and implement a course of actions required to achieve a specific teaching task in a particular context. Teacher's competency could promote their self-efficacy beliefs; teacher self- efficacy belief is an important factor for effective teaching and students' achievement. Although some of the teachers can confidently teach Integrated Science as an integrated whole some aspects proved to be a challenge to many teachers which affected their confidence during instructional process as they may need a helping hand when teaching some aspects of the subject. Personal development training of teachers enhances content knowledge as well as the classroom management skills of teachers goes a long way to boost teacher confidence and enhance their self-efficacy beliefs which affects their instructional practice.

\section{Conflict of Interest Statement}

The author whose name is listed in this manuscript certify that he has no affiliation in any entity with any financial interest or non-financial interest in the subject matter or materials discussed in this manuscript.

\footnotetext{
About the Authors

Collins Owusu-Fordjour holds a certificate in Bachelor of Science in Integrated Science Education as well as Master of Philosophy in Science Education. He is a lecturer with the Department of Integrated Science Education at the University of Education, Winneba, Ghana. He is currently pursuing PhD in Science Education. His research area is in science teaching and learning in high schools and universities.

Dr. James Awuni Azure is a Senior Lecturer in the Department of Biology Education in the University of Education, Winneba. His research interest is in science education.

Dr. Charles Kwesi Koomson is also a lecturer in the Department of Integrated Science Education in the University of Education, Winneba. He has a research interest in entomology and science education.
} 


\section{References}

Anamuah-Mensah, J., \& Benneh, B. (2010). Particular issues of teacher education in Ghana. The UNESCO Teacher Training Initiative for Sub-Saharan Africa. Accra: Ghana.

Bandura, A. (1997). Self-efficacy: The exercise of control. New York, NY: W.H. Freeman.

Bernat, E., \& Gvozdenko, I. (2005). Beliefs about Language Learning: Current Knowledge, Pedagogical Implications, and New Research Directions. TESL-EJ, 9(1), 1-21.

Coladarci, T. (1992). Teachers' sense of efficacy and commitment to teaching. Journal of Experimental Education, 60, 323-337.

Conant, J. (1963). The Teacher and the Taught: Education in Theory and Practice from Plato. (R. Gross, Ed.) New York: The Dell Publishing Company.

Donaghue, H. (2003). An Instrument to Elicit Teachers' Beliefs and Assumptions. ELT Journal, 57(4), 344-351.

Elloitt, P. (2010). Science and literacy in the elementary classroom. Research Monograph(26), 1 - 4.

Guerrero, L. K., \& Floyd, K. (2006). Nonverbal communication in close relationships. Mahwah, NJ: Lawrence Erlbaum Associates.

Jones, K. (2008). Will education be powerful enough to provide satisfying employment and economic stability? Career Development: NCDA Magazine, 2, 2228.

Jurik, V. E. (2014). Predicting students' cognitive learning activity and intrinsic learning motivation: How powerful are teacher statements, student profiles, and gender? Learning and Individual Differences, 32, 132-139.

Kenneth, D. M. (2007). Classroom Teaching Skill. Edisi ke-6: McGraw Hill.

Mansfield, C. F., \& Woods-McConney, A. (2012). I didn't always perceive myself as a science person: Examining efficacy for primary science teaching. Australian Journal of Teacher Education, 37(10), 37-52.

Ormrod, J. E. (2006). Educational psychology: Developing learners. Upper Saddle River, NJ: Pearson Merrill Prentice Hall.

Pajares, M. F. (1992). Teachers' beliefs and education research: Cleaning up a messy construct. Review of Educational Research(62), 307-332.

Wimsatt, M. A. (2012). One Instructor Teaching Multiple Online Graduate-Level Courses: Are There Differences. International Journal of Education, 3 (2), E5. 

be applied to their work. Under the terms of this license, no permission is required from the author(s) or publisher for members of the community to copy, distribute, transmit or adapt the article content, providing a proper, prominent and unambiguous attribution to the authors in a manner that makes clear that the materials are being reused under permission of a Creative Commons License. Views, opinions and conclusions expressed in this research article are views, opinions and conclusions of the author(s). Open Access Publishing Group and European Journal of Open Education and E-learning Studies shall not be responsible or answerable for any loss, damage or liability caused in relation to/arising out of conflict of interests, copyright violations and inappropriate or inaccurate use of any kind content related or integrated on the research work. All the published works are meeting the Open Access Publishing requirements and can be freely accessed, shared, modified, distributed and used in educational, commercial and non-commercial purposes under a Creative Commons Attribution 4.0 International License (CC BY 4.0). 